\title{
Dual properties of water-soluble Ru-PTA complexes of dendrimers: catalysis and interaction with DNA
}

Paul Servin, ${ }^{\mathrm{a}, \mathrm{b}}$ Régis Laurent, ${ }^{\mathrm{a}, \mathrm{b}}$ Mar Tristany, ${ }^{\mathrm{a}, \mathrm{b}}$ Antonio Romerosa, ${ }^{\mathrm{c}}$ Maurizio Peruzzini, ${ }^{\mathrm{d}}$ Federico Garcia-Maroto, ${ }^{\mathrm{e}}$ Jean-Pierre Majoral, ${ }^{\mathrm{a}, \mathrm{b}}$ Anne-Marie Caminade ${ }^{\mathrm{a}, \mathrm{b}, * 1}$

a CNRS, LCC (Laboratoire de Chimie de Coordination), 205 route de Narbonne, BP 44099, F-31077 Toulouse Cedex 4, France.

${ }^{\mathrm{b}}$ Université de Toulouse, UPS, INPT, F-31077 Toulouse Cedex 4, France.

c Área de Química Inorgánica-CIESOL, Universidad de Almería, 04071 Almería, Spain

d ICCOM CNR, Istituto di Chimica dei Composti Organometallici, Via Madonna del Piano, 10 Polo Scientifico di Sesto Fiorentino, 50019, Sesto, Fiorentino, Italy.

e Área de Bioquímica y Biología Molecular, Universidad de Almería, 04071 Almería, Spain

Dedicated to Prof. Dr. Carlo Mealli, on the occasion of his $70^{\text {th }}$ birthday

\begin{abstract}
.
Phosphorhydrazone dendrimers ended by PTA (1,3,5-triaza-7-phosphaadamantane) derivatives are used for the complexation of ruthenium. The corresponding complexes, either isolated (synthesized ex situ, i.e. preformed) or generated in situ are used as catalysts for the hydration of phenylacetylene in various conditions (ex situ or in situ, quantities, temperature, duration, co-catalyst or not, recycling). The same preformed complexes are tested for their interaction with supercoiled DNA, to afford relaxed DNA.
\end{abstract}

Keywords. Dendrimers; complexes; PTA phosphine; homogeneous catalysis; DNA interaction.

\footnotetext{
$1 *$ Corresponding author.

E-mail addresses: paul.servin@xeroscleaning.com (P. Servin), regis.laurent@1cc-toulouse.fr (R. Laurent), mar.tristany@gmail.com (M.Tristany),romerosa@ual.es (A. Romerosa), maurizio.peruzzini@iccom.cnr.it (M. Peruzzini), fgmaroto@ual.es (F. Garcia-Maroto), jean-pierre.majoral@lcc-toulouse.fr (J.P. Majoral), annemarie.caminade@1cc-toulouse.fr (A.M. Caminade)
} 


\section{Introduction}

Dendrimers are hyperbranched macromolecules synthesized from a central core, using repetitive branching elements. Thanks to their step-by-step synthesis, they have a perfectly defined multifunctionalized structure, contrarily to that of polymers. The presence of multiple terminal functions, easily accessible, is certainly the most important characteristic of dendrimers, which enables their use in many different fields [1]. Different types of dendrimers exist, depending on the nature of their internal structure, which can be purely organic as for instance for PAMAM [2] and PPI [3] dendrimers, but also partly inorganic [4], such as carbosilane [5] and phosphorhydrazone [6] dendrimers. Specific terminal functions of dendrimers have to be chosen to fulfill specific properties. For instance in the case of phosphorhydrazone dendrimers, organometallic complexes [7] for catalysis [8-11], or watersolubilizing functions for biology [12-15] have been synthesized. The use of the same dendrimers in radically different fields is an exception, but organometallic dendrimers ended by coordination complexes are interesting candidates in this topic [16]. Indeed, we have previously reported that poly(phosphorhydrazone) dendrimers ended by analogous (but not strictly identical) copper complexes of pyridineimine terminal ligands have catalytic properties [17], and are able to fight in vitro against various cancer cell lines [18,19].

An important question to observe dual properties with a same dendrimer is the solubility, in particular the solubility in aqueous media if one of the properties concerns biology. Water solubility is generally attained with most dendrimers when having charges (positive or negative) on the terminal functions [20,21]. We have previously reported the synthesis of phosphorhydrazone dendrimers functionalized by PTA (1,3,5-triaza-7-phosphaadamantane [22-26]), and preliminary catalysis experiments with the corresponding $\mathrm{Ru}$ complexes, synthesized ex situ (preformed) [27]. The structure of the free and complexed compounds previously synthesized is shown in Figure 1, from generations 1 to 3 of the dendrimers $\left(\mathbf{G}_{\mathbf{1}}\right.$, $\mathbf{G}_{2}, \mathbf{G}_{3}$, and $\mathbf{G}_{\mathbf{1}}-\mathbf{R u}_{\mathbf{1 2}}, \mathbf{G}_{\mathbf{2}}-\mathbf{R} \mathbf{u}_{\mathbf{2}}, \mathbf{G}_{\mathbf{3}}-\mathbf{R} \mathbf{u}_{\mathbf{4}}$ ) and the monomers ( $\mathbf{M}$ and $\mathbf{M}-\mathbf{R u}$ ), together with the newly synthesized $\mathbf{G}_{\mathbf{0}}$ and $\mathbf{G}_{\mathbf{0}}-\mathbf{R u}_{\mathbf{6}}$. The PTA is linked to the dendrimers through the alkylation of one nitrogen atom, thus affording dendrimers which, are soluble in water media, in particular in the water/isopropanol mixtures in which the catalytic experiments were carried out [27].

In this paper, we will report more insights in the catalytic properties of these dendrimers (the preformed complexes, or the free PTA-dendrimers to which the ruthenium is added in situ), and a preliminary biological experiment, concerning their interaction with supercoiled DNA, in comparison with cisplatin. 


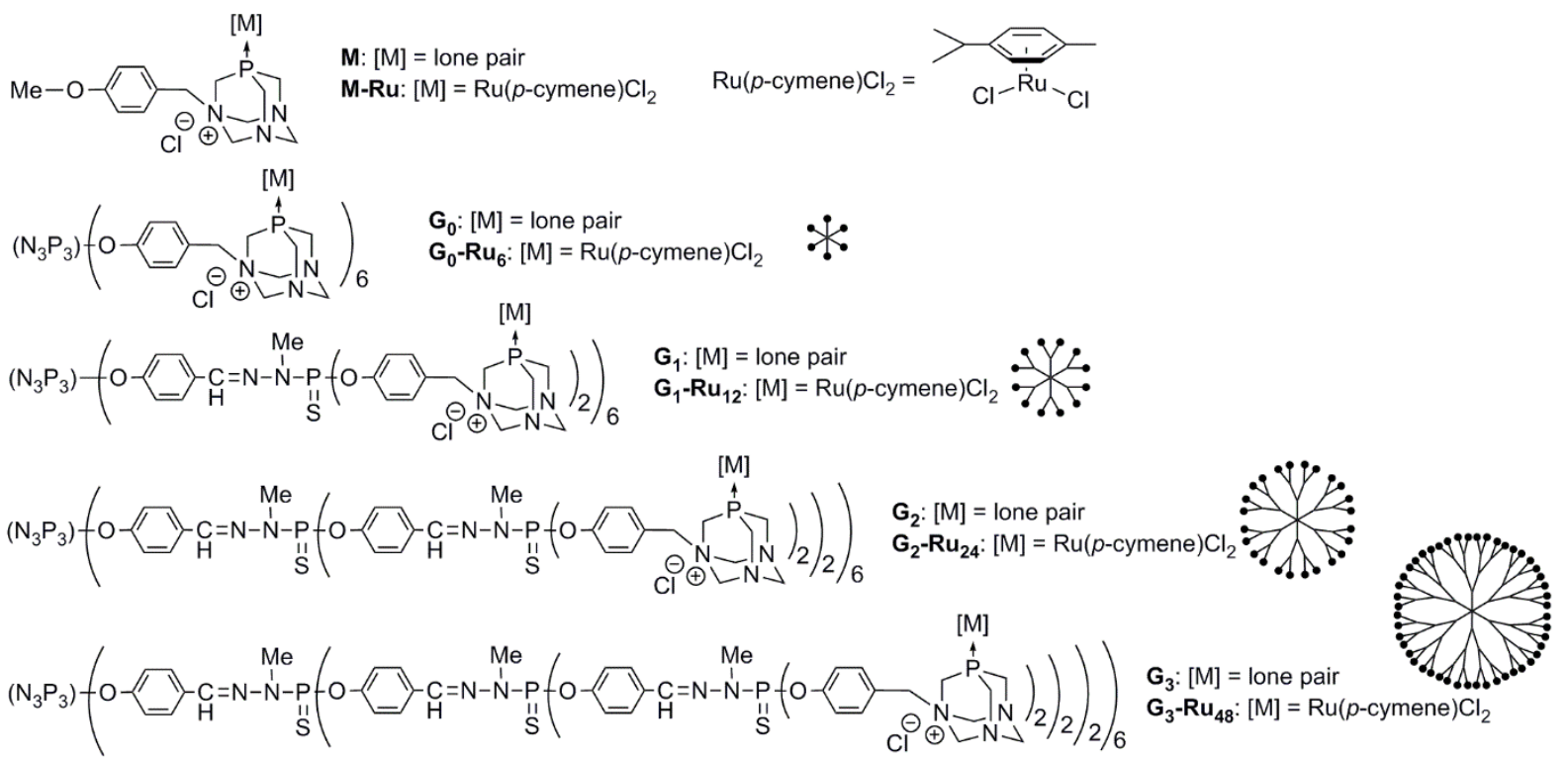

Figure 1. Monomer and dendrimers functionalized by PTA $\left(\mathbf{M}, \mathbf{G}_{\mathbf{0}}, \mathbf{G}_{\mathbf{1}}, \mathbf{G}_{\mathbf{2}}, \mathbf{G}_{\mathbf{3}}\right)$, and the corresponding ruthenium complexes (M-Ru, $\left.\mathbf{G}_{\mathbf{0}}-\mathbf{R} \mathbf{u}_{6}, \mathbf{G}_{\mathbf{1}}-\mathbf{R} \mathbf{u}_{12}, \mathbf{G}_{2}-\mathbf{R} \mathbf{u}_{24}, \mathbf{G}_{3}-\mathbf{R} \mathbf{u}_{48}\right)$. The linear representation is used, but these compounds have a tridimensional branched structure, as schematized on the right.

\section{Experimental}

\subsection{General.}

All reactions were carried out under argon, using standard Schlenk techniques. All solvents were distilled (toluene, THF and ether over sodium/benzophenone, pentane over phosphorus pentoxide, and $\mathrm{CH}_{2} \mathrm{Cl}_{2}$ over $\mathrm{CaH}_{2}$ ), and degassed when phosphines were used. ${ }^{1} \mathrm{H},{ }^{13} \mathrm{C},{ }^{31} \mathrm{P}$ NMR spectra were recorded with Bruker AC 200, AC 250, or DPX 300 spectrometers. References for NMR chemical shifts are $85 \% \mathrm{H}_{3} \mathrm{PO}_{4}$ for ${ }^{31} \mathrm{P} \mathrm{NMR}, \mathrm{SiMe}_{4}$ for ${ }^{1} \mathrm{H}$ and ${ }^{13} \mathrm{C}$ NMR. The numbering used for NMR assignments is depicted in Figure 2. Monomers $\mathbf{M}$ and $\mathbf{M}-\mathbf{R u}$, dendrimers $\mathbf{G}_{\mathbf{1}}, \mathbf{G}_{\mathbf{2}}, \mathbf{G}_{\mathbf{3}}, \mathbf{G}_{\mathbf{1}}-\mathbf{R} \mathbf{u}_{\mathbf{1 2}}, \mathbf{G}_{\mathbf{2}}-\mathbf{R} \mathbf{u}_{\mathbf{2 4}}$, and $\mathbf{G}_{\mathbf{3}}-\mathbf{R} \mathbf{u}_{48}$ were synthesized as published [27], as well as compound $\mathbf{1 - G _ { 0 }}$ [28].

\subsection{Synthesis and characterization of $2-G_{0}$}

A solution of borane dimethyl sulfide-complex $1.0 \mathrm{M}$ in dichloromethane $(7 \mathrm{~mL}, 7 \mathrm{mmol})$ was added to a solution of $\mathbf{1}-\mathbf{G}_{\mathbf{0}}(2 \mathrm{~g}, 2.32 \mathrm{mmol})$ in dichloromethane $(80 \mathrm{~mL})$ at $0^{\circ} \mathrm{C}$ and the mixture was left stirring overnight. When there was no more aldehyde, solvent was removed in vacuum and methanol was added till all solid was solubilized, and then was again evaporated. This procedure was repeated two times more to afford $\mathbf{2}-\mathbf{G}_{\mathbf{0}}$ (2 g, 2.3 mmol, 99\% 
yield) as a white powder. ${ }^{1} \mathrm{H}$ NMR (250 MHz, DMSO-d6) $\delta(\mathrm{ppm}): 4.47\left(\mathrm{~d}, J_{\mathrm{HH}}=5.5 \mathrm{~Hz}\right.$, $\left.12 \mathrm{H}, \mathrm{CH}_{2}\right), 5.24\left(\mathrm{t}, J_{\mathrm{HH}}=5.5 \mathrm{~Hz}, 6 \mathrm{H}, \mathrm{OH}\right), 6.8\left(\mathrm{~d}, J_{\mathrm{HH}}=8.4 \mathrm{~Hz}, 12 \mathrm{H}, \mathrm{C}_{2} \mathrm{H}\right), 7.20\left(\mathrm{~d}, J_{\mathrm{HH}}=\right.$ $\left.8.4 \mathrm{~Hz}, 12 \mathrm{H}, \mathrm{C}_{3} \mathrm{H}\right) .{ }^{31} \mathrm{P}\left\{{ }^{1} \mathrm{H}\right\}$ NMR (81 MHz, DMSO-d6) $\delta$ ppm: 12.3 (s). ${ }^{13} \mathrm{C}\left\{{ }^{1} \mathrm{H}\right\}$ NMR (62.9 MHz, DMSO-d6) $\delta$ (ppm): 62.17 (s, $\left.\mathrm{CH}_{2} \mathrm{OH}\right), 120.01$ (s, $\left.\mathrm{C}_{2} \mathrm{H}\right), 127.59$ (s, $\left.\mathrm{C}_{3} \mathrm{H}\right), 139.36$ (s, $\left.\mathrm{C}_{4}\right), 148.53\left(\mathrm{~s}, \mathrm{C}_{1}\right)$. MS (DCI/ $\mathrm{NH}_{3}$, positive, $\left.\mathrm{MeOH}\right) \mathrm{m} / \mathrm{z}$ for $\mathrm{C}_{42} \mathrm{H}_{42} \mathrm{~N}_{3} \mathrm{O}_{12} \mathrm{P}_{3}: 874.3[\mathrm{M}+1]$.

\subsection{Synthesis and characterization of 3-Go}

Thionyl chloride ( $8 \mathrm{~mL}, 0.109 \mathrm{mmol}$ ) was added dropwise to dendrimer $\mathbf{2}-\mathbf{G}_{\mathbf{0}}$ (1.058 g, 1.2 mmol) in solid state under stirring on an ice bath till dendrimer was dissolved and the mixture was left overnight. Toluene was added to the mixture and the excess of thionyl chloride was co-evaporated (3 times). The dendrimer was precipitated in THF:pentane (1:10) to afford 3$\mathbf{G}_{\mathbf{0}}\left(1.09 \mathrm{~g}, 1.1 \mathrm{mmol}, 92 \%\right.$ yield) as a white powder. ${ }^{1} \mathrm{H} \mathrm{NMR}\left(250 \mathrm{MHz}, \mathrm{CDCl}_{3}\right) \delta(\mathrm{ppm})$ : $4.59\left(\mathrm{~s}, 12 \mathrm{H}, \mathrm{CH}_{2} \mathrm{Cl}\right), 6.94\left(\mathrm{~d}, J_{\mathrm{HH}}=8.4 \mathrm{~Hz}, 12 \mathrm{H}, \mathrm{C}_{2} \mathrm{H}\right), 7.25\left(\mathrm{~d}, J_{\mathrm{HH}}=8.4 \mathrm{~Hz}, 12 \mathrm{H}, \mathrm{C}_{3} \mathrm{H}\right)$. ${ }^{31} \mathrm{P}\left\{{ }^{1} \mathrm{H}\right\} \operatorname{NMR}\left(81 \mathrm{MHz}, \mathrm{CDCl}_{3}\right) \delta(\mathrm{ppm}): 12.2$ (s). ${ }^{13} \mathrm{C}\left\{{ }^{1} \mathrm{H}\right\} \mathrm{NMR}\left(62.9 \mathrm{MHz}, \mathrm{CDCl}_{3}\right) \delta$ (ppm): 45.59 (s, $\left.\mathrm{CH}_{2} \mathrm{Cl}\right), 121.20\left(\mathrm{~s}, \mathrm{C}_{2} \mathrm{H}\right), 129.92\left(\mathrm{~s}, \mathrm{C}_{3} \mathrm{H}\right), 134.31\left(\mathrm{~s}, \mathrm{C}_{4}\right), 150.31\left(\mathrm{~s}, \mathrm{C}_{1}\right) . \mathrm{MS}$ (DCI/NH 3 , positive, $\mathrm{CDCl}_{3}$ ) $\mathrm{m} / \mathrm{z}$ for $\mathrm{C}_{42} \mathrm{H}_{36} \mathrm{Cl}_{6} \mathrm{~N}_{3} \mathrm{O}_{6} \mathrm{P}_{3}: 984.2[\mathrm{M}+1]^{+}$.

\subsection{Synthesis and characterization of $G_{0}$}

A solution of PTA (471 mg, $3 \mathrm{mmol}$ ) in $\mathrm{MeOH}$ (48 mL, degassed) was added to a solution of dendrimer $\mathbf{3}-\mathbf{G}_{\mathbf{0}}(420 \mathrm{mg}, 0.427 \mathrm{mmol})$ in THF (15 mL, degassed) and the mixture was let stirring at room temperature ( ${ }^{31} \mathrm{P}-\mathrm{NMR}$ monitoring, 1day). Solvents were removed in vacuum and the residue was washed with degassed THF ( 3 times) to afford $\mathbf{G}_{0}(820 \mathrm{mg}, 0.425 \mathrm{mmol}$, $99 \%$ yield) as a white powder. ${ }^{1} \mathrm{H}$ NMR $(250 \mathrm{MHz}, \mathrm{DMSO}-\mathrm{d} 6) \delta(\mathrm{ppm}): 3.72\left(\mathrm{dd}, J_{\mathrm{HH}}=14\right.$ $\left.\mathrm{Hz}, J_{\mathrm{HP}}=8 \mathrm{~Hz}, 12 \mathrm{H}, \mathrm{C}_{7} \mathrm{H}^{\mathrm{a}}\right), 3.85\left(\mathrm{dd}, J_{\mathrm{HH}}=14 \mathrm{~Hz}, J_{\mathrm{HP}}=12 \mathrm{~Hz}, 12 \mathrm{H}, \mathrm{C}_{7} \mathrm{H}^{\mathrm{b}}\right), 4.22($ br s, $24 \mathrm{H}$, $\left.\mathrm{C}_{5} \mathrm{H}_{2}, \mathrm{C}_{6} \mathrm{H}_{2}\right), 4.36\left(\mathrm{~d}, J_{\mathrm{HH}}=13.5 \mathrm{~Hz}, 6 \mathrm{H}, \mathrm{C}_{9} \mathrm{H}^{\mathrm{a}}\right), 4.51\left(\mathrm{~d}, J_{\mathrm{HH}}=13.5 \mathrm{~Hz}, 6 \mathrm{H}, \mathrm{C}_{9} \mathrm{H}^{\mathrm{b}}\right), 4.82(\mathrm{~d}$, $\left.J_{\mathrm{HH}}=10.6 \mathrm{~Hz}, 12 \mathrm{H}, \mathrm{C}_{8} \mathrm{H}^{\mathrm{a}}\right), 5.04\left(\mathrm{~d}, J_{\mathrm{HH}}=10.6 \mathrm{~Hz}, 12 \mathrm{H}, \mathrm{C}_{8} \mathrm{H}^{\mathrm{b}}\right), 7.01\left(\mathrm{~d}, J_{\mathrm{HH}}=7.5 \mathrm{~Hz}, 12 \mathrm{H}\right.$, $\left.\mathrm{C}_{2} \mathrm{H}\right), 7.49\left(\mathrm{~d}, J_{\mathrm{HH}}=7.5 \mathrm{~Hz}, 12 \mathrm{H}, \mathrm{C}_{3} \mathrm{H}\right) .{ }^{31} \mathrm{P}\left\{{ }^{1} \mathrm{H}\right\}$ NMR (101.25 MHz, DMSO-d6) $\delta(\mathrm{ppm})$ : 83.7 (s, P $\mathrm{PTA}), 8.3$ (s, $\left.\mathrm{P}_{\text {core }}\right) .{ }^{13} \mathrm{C}\left\{{ }^{1} \mathrm{H}\right\}$ NMR (62.9 MHz, DMSO-d6) $\delta(\mathrm{ppm}): 45.78\left(\mathrm{~d}, J_{\mathrm{HP}}=\right.$ $\left.20.5 \mathrm{~Hz}, \mathrm{C}_{7} \mathrm{H}_{2}\right), 52.26\left(\mathrm{~d}, J_{\mathrm{HP}}=20.5 \mathrm{~Hz}, \mathrm{C}_{6} \mathrm{H}_{2}\right), 64.09\left(\mathrm{~s}, \mathrm{C}_{5} \mathrm{H}_{2}\right), 69.69\left(\mathrm{~s}, \mathrm{C}_{9} \mathrm{H}_{2}\right), 79.20(\mathrm{~s}$, $\left.\mathrm{C}_{8} \mathrm{H}_{2}\right), 121.49\left(\mathrm{~s}, \mathrm{C}_{2} \mathrm{H}\right), 123.54\left(\mathrm{~s}, \mathrm{C}_{4}\right), 135.12\left(\mathrm{~s}, \mathrm{C}_{3} \mathrm{H}\right), 151.39\left(\mathrm{~s}, \mathrm{C}_{1}\right)$.

\subsection{Synthesis and characterization of $G_{0}-R u_{6}$}

A solution of dichloro(p-cymene)ruthenium dimer ([RuCl $2(p$-cymene $)]_{2}, 304 \mathrm{mg}, 0.496$ mmol) in a solvent mixture of THF:MeOH 1:4 (5 mL, degassed) (some drops of $\mathrm{CH}_{2} \mathrm{Cl}_{2}$ and 
heating) was added to a solution of dendrimer $\mathbf{G}_{\mathbf{0}}(334 \mathrm{mg}, 0.174 \mathrm{mmol})$ in a solvent mixture of THF:MeOH (degassed) 1:4 (20 mL) and the mixture was left stirring 2 hours at room temperature. The solvents were removed in vacuum and the residue was washed several times with THF and $\mathrm{CH}_{2} \mathrm{Cl}_{2}$ to afford $\mathbf{G}_{0}-\mathbf{R u}_{6}(448 \mathrm{mg}, 0.111 \mathrm{mmol}, 64 \%$ yield) as an orange powder. ${ }^{1} \mathrm{H}$ NMR (300 MHz, DMSO-d6) $\delta(\mathrm{ppm}): 1.09$ (d, $\left.J_{\mathrm{HH}}=6.6 \mathrm{~Hz}, 36 \mathrm{H}, \mathrm{C}_{16} \mathrm{H}_{3}\right), 1.9$ (s, $\left.18 \mathrm{H}, \mathrm{C}_{10} \mathrm{H}_{3}\right), 2.70\left(\mathrm{~m}, 6 \mathrm{H}, \mathrm{C}_{15} \mathrm{H}\right), 4.0-4.2$ (m, 12H, $\mathrm{C}_{5} \mathrm{H}_{2}$ ), 4.2-4.8 (br m, 48H, $\mathrm{C}_{6} \mathrm{H}_{2}, \mathrm{C}_{7} \mathrm{H}_{2}$, $\mathrm{C}_{9} \mathrm{H}_{2}$ ), 5.06 (br s, $12 \mathrm{H}, \mathrm{C}_{8} \mathrm{H}^{\mathrm{a}}$ ), 5.36 (br s, $12 \mathrm{H}, \mathrm{C}_{8} \mathrm{H}^{\mathrm{b}}$ ), 5.9 (m, 24H, $\left.\mathrm{C}_{12} \mathrm{H}, \mathrm{C}_{13} \mathrm{H}\right), 6.96$ (br d, $\left.J_{\mathrm{HH}}=7.8 \mathrm{~Hz}, 12 \mathrm{H}, \mathrm{C}_{2} \mathrm{H}\right), 7.44$ (br s, $\left.12 \mathrm{H}, \mathrm{C}_{3} \mathrm{H}\right) .{ }^{31} \mathrm{P}\left\{{ }^{1} \mathrm{H}\right\}$ NMR (121. $\left.5 \mathrm{MHz}, \mathrm{DMSO}-\mathrm{d} 6\right) \delta$ (ppm): -18.1 (s, Р РтА $), 8.6$ (s, $\left.\mathrm{P}_{\text {core }}\right) .{ }^{13} \mathrm{C}\left\{{ }^{1} \mathrm{H}\right\}$ NMR (75.5 MHz, DMSO-d6) $\delta(\mathrm{ppm}): 18.34$ (s, $\left.\mathrm{C}_{10} \mathrm{H}_{3}\right), 22.12\left(\mathrm{~s}, \mathrm{C}_{16} \mathrm{H}_{3}\right), 30.50\left(\mathrm{~s}, \mathrm{C}_{15} \mathrm{H}\right), 45.57$ (br d, $\left.J_{\mathrm{HP}}=20.0 \mathrm{~Hz}, \mathrm{C}_{7} \mathrm{H}_{2}\right), 52.14\left(\mathrm{~m}, \mathrm{C}_{6} \mathrm{H}_{2}\right)$, 63.21 (br s, $\mathrm{C}_{5} \mathrm{H}_{2}$ ), 69.13 (br s, $\mathrm{C}_{9} \mathrm{H}_{2}$ ), 79.10 (br s, $\mathrm{C}_{8} \mathrm{H}_{2}$ ), 86.20 (br s, $\mathrm{C}_{12} \mathrm{H}$ ), 89.30 (br s, $\left.\mathrm{C}_{13} \mathrm{H}\right), 97.41\left(\mathrm{~s}, \mathrm{C}_{11}\right), 106.23\left(\mathrm{~s}, \mathrm{C}_{14}\right), 121.63\left(\mathrm{~s}, \mathrm{C}_{2} \mathrm{H}\right), 123.60\left(\mathrm{~s}, \mathrm{C}_{4}\right), 135.20\left(\mathrm{~s}, \mathrm{C}_{3} \mathrm{H}\right), 151.30$ $\left(\mathrm{s}, \mathrm{C}_{1}\right)$.

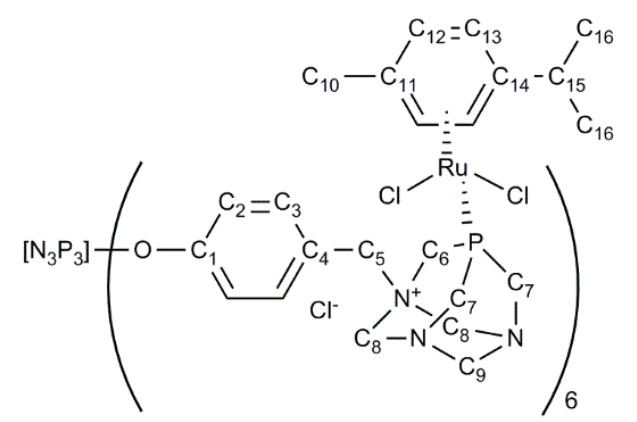

Figure 2. Numbering used for NMR assignment.

\subsection{Catalytic tests}

All catalytic reactions were performed in Schlenk tubes, with strong magnetic stirring, and warm oil bath. The percentage of conversion and the selectivity were measured by relative integration of ${ }^{1} \mathrm{H}$ NMR signals. Experiments have been done in duplicate, and the values given are the mean values (generally \pm 2 ).

Catalyzes with the Ru complexes $\boldsymbol{M - R \boldsymbol { u }}, \boldsymbol{G}_{1}-\boldsymbol{R} \boldsymbol{u}_{12}, \boldsymbol{G}_{2}-\boldsymbol{R} \boldsymbol{u}_{24}$, and $\boldsymbol{G}_{3}-\boldsymbol{R} \boldsymbol{u}_{48}$ : in the Schlenk tube were mixed $1 \mathrm{~mL}$ of water, $3 \mathrm{~mL}$ of isopropanol, $0.11 \mathrm{~mL}(1.0 \mathrm{mmol})$ of phenylacetylene, 5.0 $10^{-2} \mathrm{mmol}$ of preformed Ru complex (31.0 mg of M-Ru, $36.0 \mathrm{mg}$ of $\mathbf{G}_{\mathbf{1}}-\mathbf{R} \mathbf{u}_{\mathbf{1 2}}, 38.5 \mathrm{mg}$ of $\mathbf{G}_{\mathbf{2}}$ $\mathbf{R u}_{24}$, and $39.6 \mathrm{mg}$ of $\mathbf{G}_{\mathbf{3}}-\mathbf{R} \mathbf{u}_{48}$ ). These mixtures afforded a single phase in all cases. They were stirred for 24 or $48 \mathrm{~h}$ at $90^{\circ} \mathrm{C}$.

Catalyzes with the complexes formed in situ: in the Schlenk tube were mixed $1 \mathrm{~mL}$ of water, 3 $\mathrm{mL}$ of isopropanol, compounds $\mathbf{M}, \mathbf{G}_{\mathbf{1}}, \mathbf{G}_{\mathbf{2}}$, or $\mathbf{G}_{\mathbf{3}}$, and $\left[\mathrm{RuCl}_{2} \text { (p-cymene) }\right]_{2}$, using 1.1 equiv. of PTA for 1 equiv. of $\mathrm{Ru}$. The mixture was left to react for $15 \mathrm{~min}$ at room temperature, then 
phenylacetylene (100 equiv.), and $\mathrm{H}_{2} \mathrm{SO}_{4}$ (co-catalyst, 10 equiv.) were added, then the heating was started.

Recycling experiment: the first run was carried out in the conditions used for the complexes formed in situ (with $\mathbf{M}$ and $\mathbf{G 1}$ ), followed by heating for $17 \mathrm{~h}$ at $90^{\circ} \mathrm{C}$. At the end of the first run, an extraction was made with diethylether. A new portion of isopropanol and of phenylacetylene was added, and the catalysis was again carried out at $90^{\circ} \mathrm{C}$ for $17 \mathrm{~h}$ (second run).

\subsection{Interactions with DNA}

The complexes $\mathbf{M}-\mathbf{R u}, \mathbf{G}_{\mathbf{0}}-\mathbf{R} \mathbf{u}_{\mathbf{6}}, \mathbf{G}_{\mathbf{1}}-\mathbf{R} \mathbf{u}_{12}, \mathbf{G}_{\mathbf{2}}-\mathbf{R} \mathbf{u}_{\mathbf{2}}$, and $\mathbf{G}_{\mathbf{3}}-\mathbf{R} \mathbf{u}_{48}$ were first evaporated under vacuum for a long time (48h) to eliminate traces of organic solvents, then they were tentatively dissolved in phosphate buffer. $\mathbf{G}_{3}-\mathbf{R} \mathbf{u}_{48}$ was insoluble and was discarded at this step. $\mathbf{G}_{\mathbf{1}}-\mathbf{R} \mathbf{u}_{12}$ and $\mathbf{G}_{\mathbf{2}}-\mathbf{R} \mathbf{u}_{24}$ have a low solubility in these conditions, but they were used, as well as $\mathbf{M}-\mathbf{R u}$ and $\mathbf{G}_{\mathbf{0}}-\mathbf{R u}_{\mathbf{6}}$ (which are fairly soluble) for interaction with supercoiled DNA. One microgram of the pBluescript KSII plasmid (3Kbp; Stratagene ${ }^{\mathrm{TM}}$ ) was added to $20 \mu \mathrm{L}$ of $10 \mathrm{mM}$ phosphate buffer solution at $\mathrm{pH} 7.0$ and diluted with the appropriate amount of a freshly prepared solution of the ruthenium complexes in the same phosphate buffer to achieve the desired stoichiometry between the nucleobase and the ruthenium complex. The reaction mixtures were then incubated for $14 \mathrm{~h}$ at $37{ }^{\circ} \mathrm{C}$ in the dark, and $10 \mu \mathrm{L}$ sample-aliquots were withdrawn and analyzed by electrophoresis in 1\% agarose-TAE gels. DNA bands were visualized by staining with ethidium bromide and photographed under UV light. The Ri value (metal to base molar ratio at the onset of the incubation) at which complete transformation of the supercoiled to relaxed form of the plasmid was registered for each active compound.

The result of the interactions was determined by DNA mobility shift assays, and compared with the results of cisplatin $\left(\right.$ cis- $\left.\left[\mathrm{PtCl}_{2}\left(\mathrm{NH}_{3}\right)_{2}\right]\right)$. Analogous experiments were carried out by dissolving first the complexes in a small quantity of DMSO, then adding these solutions to phosphate buffer. All the compounds were soluble in these conditions, but the results of the interaction with supercoiled DNA were analogous than in the previous cases.

\section{Results and discussion}

\subsection{Catalysis.}

As a test reaction, we have chosen the catalytic hydration of alkynes. This reaction is frequently encountered in the literature, and different types of catalysts have been used, in particular mercury, but also less toxic metals such as gold, platinum and palladium, and mainly ruthenium [29]. We have previously reported the use of the preformed Ru complexes 
shown in Figure 1 for catalyzing the hydration of phenyl acetylene, and the isomerization of 1-octan-3-ol to 3-octanone. The latter experiment displayed a nice positive dendritic effect, i.e. an increase of the efficiency of the catalysis when the generation (size) of the dendrimer increased. This effect was not due to a larger number of catalytic entities, as the number of Ru-PTA entities was kept constant, by comparing the efficiency of 1 equiv. of $\mathbf{G}_{3}-\mathbf{R} \mathbf{u}_{48}$ to that of 2 equiv. of $\mathbf{G}_{\mathbf{2}}-\mathbf{R} \mathbf{u}_{\mathbf{2}}$, or 4 equiv. of $\mathbf{G}_{\mathbf{1}}-\mathbf{R} \mathbf{u}_{12}$, or 48 equiv. of $\mathbf{M}-\mathbf{R u}$. However, the hydration of phenyl acetylene was more difficult, necessitated a prolonged heating ( $48 \mathrm{~h}$ at $90^{\circ} \mathrm{C}$ ), and a negative dendritic effect in the percentage of conversion was observed on going from $\mathbf{G}_{\mathbf{1}}-\mathbf{R} \mathbf{u}_{\mathbf{1 2}}$ to $\mathbf{G}_{\mathbf{3}}-\mathbf{R} \mathbf{u}_{48}$, albeit a slight improvement in the selectivity was observed [27]. Thus we decided to modify the conditions of the catalyzed hydration of acetylene, to try to get better results (Scheme 1).

It is known that metal-catalyzed hydration of alkynes provides an important route to carbonyl compounds [30], with complete atom economy. In general, addition of water to terminal alkynes follows Markovnikov's rule, leading mainly to ketones. In the case of ruthenium derivatives used as catalysts for such reactions, the ketones are generally obtained, but the anti-Markovnikov product (the aldehyde) was obtained using a $\mathrm{Ru}$ catalyst in the presence of water [31]. In the case of our preformed dendritic complexes, only small quantities of aldehyde were obtained (Scheme 1), and essentially with the smaller catalysts [27].

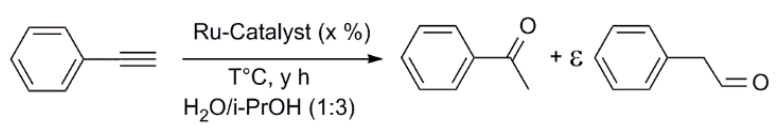

Scheme 1. Catalyzed hydration of phenylacetylene. The type of Ru catalysts, their quantities, the temperature, the time, and the selectivity (value of $\varepsilon$ ) will be given in the next Figures.

In the first experiment, we decided to check the influence of the time of reaction on the outcome of the catalysis, using the already synthesized complexes. The conditions applied were water/isopropanol $1 \mathrm{~mL}: 3 \mathrm{~mL}$, with phenylacetylene $(0.11 \mathrm{~mL}) /[\mathrm{Ru}] \quad 100: 5$, corresponding to 5 equiv. of $\mathbf{M}-\mathbf{R u}(31.0 \mathrm{mg}), 0.4166$ equiv. of $\mathbf{G}_{\mathbf{1}}-\mathbf{R} \mathbf{u}_{\mathbf{1 2}}(36.0 \mathrm{mg}), 0.2083$ equiv. of $\mathbf{G}_{2}-\mathbf{R u}_{24}(38.5 \mathrm{mg})$, and 0.1416 equiv. of $\mathbf{G}_{3}-\mathbf{R} \mathbf{u}_{48}(39.6 \mathrm{mg})$, at $90^{\circ} \mathbf{C}$ for $24 \mathrm{~h}$ (except with $\mathbf{G}_{\mathbf{2}}-\mathbf{R} \mathbf{u}_{24}$ ), and $48 \mathrm{~h}$. In this way, the number of PTA-Ru entities is identical in all experiments, whatever the generation of the dendrimer is. It can be seen from Figure 3 that the conversion is very low after $24 \mathrm{~h}$, the best result being for $\mathbf{G}_{\mathbf{1}}-\mathbf{R} \mathbf{u}_{\mathbf{1 2}}$, with $14 \%$ of conversion. The same tendency is observed after $48 \mathrm{~h}$, with $\mathbf{G}_{\mathbf{1}}-\mathbf{R} \mathbf{u}_{\mathbf{1 2}}$ being still the most 
efficient (58\% of conversion). Besides, the quantity of aldehyde increases with time, as it is not detected after $24 \mathrm{~h}$, but it is low.

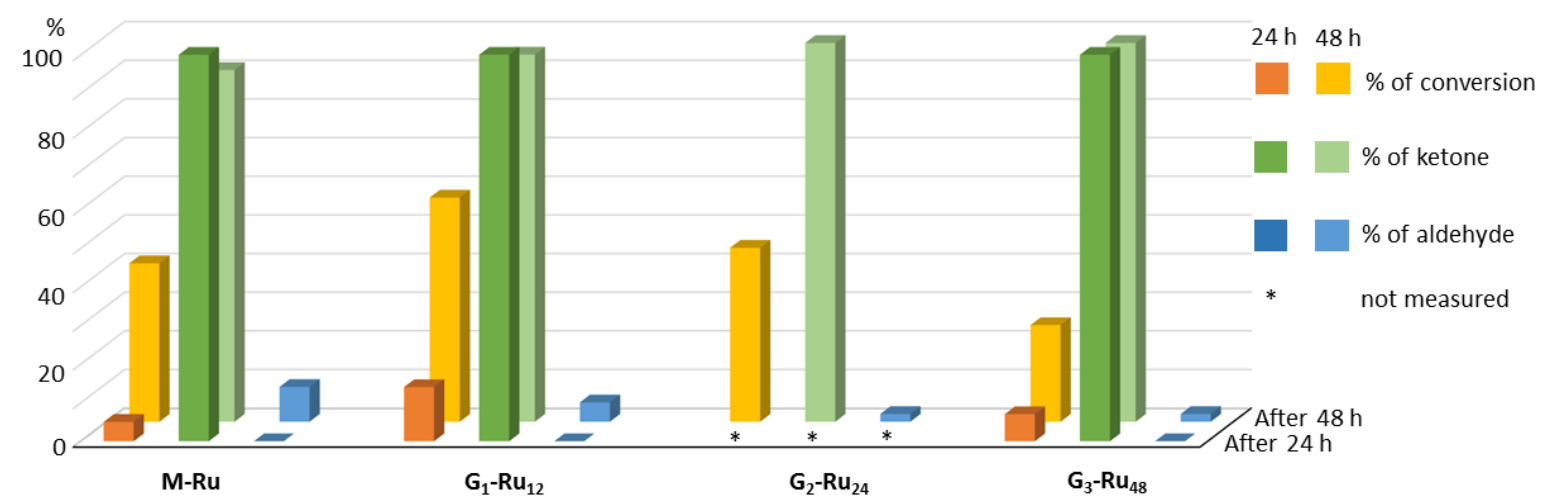

Figure 3. Percentage of conversion, percentage of ketone, and percentage of aldehyde ( $\varepsilon$ in Scheme 1), from left to right for each preformed catalyst, after $24 \mathrm{~h}$ (first row) or $48 \mathrm{~h}$ (second row), for the catalyzed hydration of phenylacetylene, using $5 \mathrm{~mol} \%$ of $\mathrm{Ru}$ complexes at $90^{\circ} \mathrm{C}$. Data after $48 \mathrm{~h}$ from reference [27].

Searching how to improve the conversion rate, we decided to use a co-catalyst, i.e. $\mathrm{H}_{2} \mathrm{SO}_{4}(10$ equiv.), which has been already proposed in the hydration of alkynes [32]. The experiment was carried out with $\mathbf{G}_{1}-\mathbf{R} \mathbf{u}_{12}$ (using only $1 \mathrm{~mol} \%$ instead of 5 in the previous experiment) at $90^{\circ} \mathrm{C}$ for $17 \mathrm{~h}$, and afforded $26 \%$ of conversion (14\% after $24 \mathrm{~h}$ without $\mathrm{H}_{2} \mathrm{SO}_{4}$ and using 5 mol\% of $\left.\mathbf{G}_{\mathbf{1}}-\mathbf{R} \mathbf{u}_{12}\right)$. Thus, the use of a co-catalyst really improved the conversion, but still the result was not totally satisfying with the complexes synthesized ex situ (preformed), thus we decided to modify the protocol by producing the complexes in situ, instead of using already prepared complexes. Several examples in the literature have already reported the comparison between preformed and in situ formed complexes for catalysis [33-37]. The in situ formation of a catalyst is most generally applied to simplify the process, and in most cases, there is no difference in the catalytic activity between pre-formed and in situ generated catalysts. However, in some cases the in situ generated catalysts outperform the preformed catalysts. Diverse explanations have been proposed, in particular the limited stability of the complexes [38-40], which is not the case of our complexes.

The first experiment was carried out with $\mathbf{G}_{\mathbf{1}}$, to which was added in situ $\left[\mathrm{RuCl}_{2}(p \text {-cymene) }]_{2}\right.$ (1.1 equiv. PTA for $1 \mathrm{Ru}$ ). $\mathrm{H}_{2} \mathrm{SO}_{4}$ and phenylacetylene were added $15 \mathrm{~min}$ after at room temperature. Then the mixture was heated for $17 \mathrm{~h}$ at $90^{\circ} \mathrm{C}$. The conversion was $68 \%$, to be compared with the experiment carried out with $\mathbf{G}_{\mathbf{1}}-\mathbf{R} \mathbf{u}_{12}$ in the same conditions (26\%). This 
result is surprising, but it has been shown previously that the in situ preparation of a catalyst from phosphines and $\left[\mathrm{RuCl}_{2}(p \text {-cymene })\right]_{2}$ was more efficient for the polymerization of acetylene than the corresponding preformed complex. This effect was tentatively assigned to the presence of free phosphines [41]. In our case, we used a slight excess of phosphine for the in situ process. Such property when using the dimer of ruthenium has been emphasized in the conclusion of a review "catalytic systems generated in situ from $\left[\mathrm{RuCl}_{2}(p \text {-cymene) }]_{2}\right.$ dimer and stable, commercially available ligand precursors usually display a similar or even higher (catalytic) activity" [42].

In view of these results, all the forthcoming experiments were carried out by forming the complexes in situ, and using 10 equiv. of co-catalyst $\left(\mathrm{H}_{2} \mathrm{SO}_{4}\right)$. In order to try to optimize both the time and the temperature, three experiments were carried out at $55^{\circ} \mathrm{C}$ for $4 \mathrm{~h}$, at $70^{\circ} \mathrm{C}$ for $17.5 \mathrm{~h}$, and at $90^{\circ} \mathrm{C}$ for $17 \mathrm{~h}$, with $\mathbf{M}(+\mathrm{Ru})$ and $\mathbf{G}_{\mathbf{1}}(+12 \mathrm{Ru})$. For both compounds, the percentage of conversion was very low after $4 \mathrm{~h}$ at $55^{\circ} \mathrm{C}(2 \%)$, but the products obtained were very different. With the monomer $\mathbf{M}$, the main product of the catalysis is the aldehyde $(52 \%$ selectivity), whereas with the dendrimer $\mathbf{G}_{\mathbf{1}}$, the only product obtained is the ketone (100\% selectivity). At $70^{\circ} \mathrm{C}$ for $17.5 \mathrm{~h}$, the conversion is still very low, with a slightly better result obtained with the dendrimer (13\% versus $10 \%)$. High conversions were observed only at $90^{\circ} \mathrm{C}$ for $17 \mathrm{~h}$. In this case, the conversion was better with the monomer $(83 \%)$ than with the dendrimer (64\%). These values are better than the results obtained when using 5\% of $\left[\mathrm{RuCl}_{2}\left(p\right.\right.$-cymene) $\left.\left\{\mathrm{P}\left(\mathrm{CH}_{2} \mathrm{OH}\right)_{3}\right\}\right]$ (instead of $1 \%$ of catalyst in our work) for the hydration of phenylacetylene at $90^{\circ} \mathrm{C}$ for $24 \mathrm{~h}$ (instead of $17 \mathrm{~h}$ ), which afforded the corresponding ketone in $89 \%$ yield [43].

Whatever the conditions, the only product of the catalysis was the ketone, when using the dendrimer, whereas a certain percentage of aldehyde was obtained in all cases with the monomer, even if this percentage decreased when the temperature increased (Figure 4).

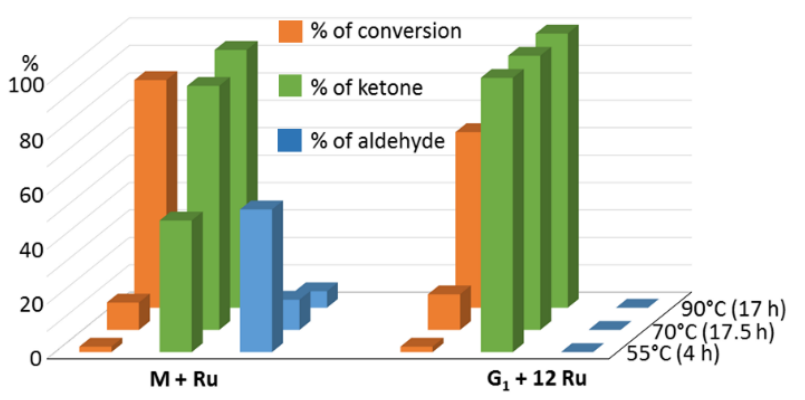

Figure 4. Percentage of conversion, percentage of ketone, and percentage of aldehyde (from left to right for each catalyst) for the catalyzed hydration of phenylacetylene, carried out at 
$55^{\circ} \mathrm{C}$ (for $4 \mathrm{~h}$ ), $70^{\circ} \mathrm{C}$ (for $17.5 \mathrm{~h}$ ), and $90^{\circ} \mathrm{C}$ (for $17 \mathrm{~h}$ ), using the monomer (M) plus $1 / 2$ $\left[\mathrm{RuCl}_{2}(\mathrm{p} \text {-cymene })\right]_{2}(\mathbf{M}+\mathbf{R u})$, or the first generation dendrimer $\left(\mathbf{G}_{\mathbf{1}}\right)$ plus $6\left[\mathrm{RuCl}_{2}(\mathrm{p}\right.$ cymene) $]_{2}\left(\mathbf{G}_{\mathbf{1}}+\mathbf{1 2} \mathbf{R u}\right)$, using $1 \mathrm{~mol} \%$ of Ru, $1.1 \mathrm{~mol} \%$ of PTA ligand, and $10 \mathrm{~mol} \%$ of $\mathrm{H}_{2} \mathrm{SO}_{4}$ as co-catalyst in both cases.

A previous experiment has demonstrated the importance of steric hindrance on the ratio aldehyde/ketone, with an increased steric hindrance favoring the formation of ketone [31]. This is coherent with our work, in which the aldehyde is observed essentially with the monomer (the least hindered complex), and traces of aldehyde are observed with the first generation dendrimer (the least hindered dendrimer). The mechanism proposed for the hydration of alkynes shows that obtaining the ketone is straightforward, with as single intermediate the complexation by the $\mathrm{Ru}$ of the triple bond, to which water adds directly. On the contrary, obtaining the aldehyde necessitates four intermediates, and in particular the rearrangement of the complex of the triple bond to a vinylidene complex [31]. One may consider that increasing the temperature should increase the rate of the straightforward addition of water to the complex of the triple bond, at the expense of its isomerization to the vinylidene complex, thus decreasing the amount of aldehyde, as we observed. Recent advances have shown the importance of heterocyclic phosphine ligands having a nitrogen capable of inner-sphere hydrogen bonding in the catalytic intermediates to lead to the aldehydes $[44,45]$, but the nitrogen atoms in our compounds are not in the appropriate location to induce such phenomenon.

As slightly better results were obtained with the dendrimer than with the monomer at $70^{\circ} \mathrm{C}$, we decided to study the evolution of the percentage of conversion with time, using the in situ $\mathrm{Ru}$ complexes of $\mathbf{M}, \mathbf{G}_{\mathbf{1}}$, and $\mathbf{G}_{\mathbf{2}}$ as catalysts. An almost linear increase of the percentage of conversion with time ( 0 to $109 \mathrm{~h}$ ) was observed in all cases. The efficiency increased in the order $\mathbf{G}_{\mathbf{2}}<\mathbf{M}<\mathbf{G}_{\mathbf{1}}$, whatever the duration of the experiment (Figure 5).

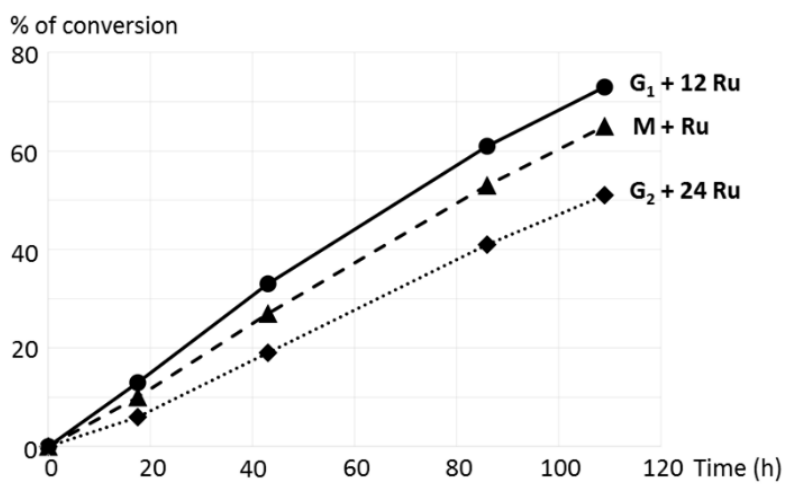


Figure 5. Evolution of the percentage of conversion with time for the catalyzed hydration of phenylacetylene, using $1 \mathrm{~mol} \%$ of Ru, $1.1 \mathrm{~mol} \%$ of PTA ligand $\left(\mathbf{M}, \mathbf{G}_{1}, \mathbf{G}_{2}\right)$, and $10 \mathrm{~mol} \%$ of $\mathrm{H}_{2} \mathrm{SO}_{4}$ as co-catalyst, at $70^{\circ} \mathrm{C}$.

These results are an illustration of the so called "dendritic effect", which corresponds to a non-linear variation of a property with the generation of the dendrimers, which is not fully understood [46]. In our case, one may propose that $\mathbf{G}_{\mathbf{1}}+\mathbf{1 2 R} \mathbf{u}$ is the best compromise between the probability for a substrate to interact with a catalytic site, and its possibility to access to the catalytic site. Indeed, if the substrate does not interact with the first catalytic site it encounters, it will interact with the second, in close proximity in the case of the dendrimers, not with the monomer; this may account for $\mathbf{M}<\mathbf{G}_{\mathbf{1}}$. On the contrary, if many catalytic sites are occupied by a substrate, the access to the remaining free sites might be impossible in the case of the larger dendrimers due to steric hindrance; this may account for $\mathbf{G}_{\mathbf{2}}<\mathbf{M}<\mathbf{G}_{\mathbf{1}}$.

One of the main motivation for using dendrimers as catalysts is the possibility to recover them and to reuse them in another catalytic experiment. Up to twelve runs with an identical catalytic efficiency have been already observed with phosphorhydrazone dendrimers [10,47]. Experiments were carried out with the in situ formed complexes of $\mathbf{M}$ and $\mathbf{G}_{\mathbf{1}}$, for $17 \mathrm{~h}$ at $90^{\circ} \mathrm{C}$ for the first run. Then an extraction was made with diethylether. A new portion of isopropanol and of phenylacetylene was added, and the catalysis was carried out again at $90^{\circ} \mathrm{C}$ for $17 \mathrm{~h}$ for the second run (Figure 6). Surprisingly, the percentage of conversion slightly increased when the monomer was reused (from 83 to $87 \%$ ), whereas it slightly decreased in the case of the $\mathbf{G}_{1}$ dendrimer (from 64 to 57\%). Most generally, dendrimers are easier to recover than monomers, as they are slightly less soluble, due to their large size. In the particular case here, the recovery is done in a two phase process, by adding ether to the mixture of water/isopropanol. The monomer is fully soluble in water, and not soluble in ether. On the contrary, the dendrimer is less soluble in water, and due to its hydrophobic internal structure, it is slightly soluble in ether. Thus the monomer is easier to recover than the dendrimer, and thus affords better results than the dendrimer when re-used.

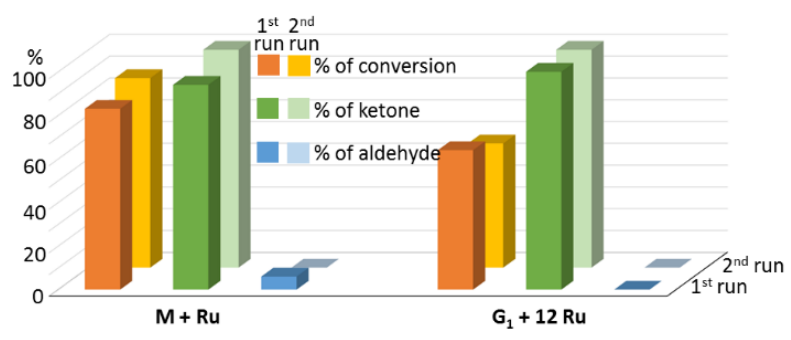


Figure 6. Recycling experiments for the catalyzed hydration of phenylacetylene. First row: first run; second row: second run (recycling). Percentage of conversion, percentage of ketone, and percentage of aldehyde (from left to right for each catalyst), after $17 \mathrm{~h}$ at $90^{\circ} \mathrm{C}$, using 1 mol\% of Ru, $1.1 \mathrm{~mol} \%$ of PTA ligand (M, $\left.\mathbf{G}_{1}\right)$, and $10 \mathrm{~mol} \%$ of $\mathrm{H}_{2} \mathrm{SO}_{4}$ as co-catalyst.

\subsection{Interaction with $D N A$}

Several ruthenium derivatives have been proposed for anti-cancer chemotherapies [48,49], almost always designed to mimic the cisplatin drug for targeting DNA, and researches in the field are very active, including for PTA, and its derivatives, complexes of Ru [50-53], thus it appeared interesting to test all the ruthenium complexes $\left(\mathbf{M}-\mathbf{R u}, \mathbf{G}_{\mathbf{1}}-\mathbf{R} \mathbf{u}_{\mathbf{1 2}}, \mathbf{G}_{\mathbf{2}}-\mathbf{R} \mathbf{u}_{\mathbf{2 4}}\right.$, and $\mathbf{G}_{\mathbf{3}^{-}}$ Ru48) for their possible interaction with DNA. All the catalytic experiments have been carried out in mixtures water/isopropanol, in which all these complexes are fairly soluble. However, for the biological experiments, it is better to have compounds soluble in pure water or in buffers. $\mathbf{M - R u}$ is well soluble in water, $\mathbf{G}_{\mathbf{1}}-\mathbf{R} \mathbf{u}_{12}$ and $\mathbf{G}_{\mathbf{2}}-\mathbf{R} \mathbf{u}_{24}$ are poorly soluble in water, and $\mathbf{G}_{3}-\mathbf{R} \mathbf{u}_{48}$ is totally insoluble in water, and thus has been discarded for the biological experiments. In view of the large difference in water solubility between $\mathbf{M}-\mathbf{R u}$ and $\mathbf{G}_{\mathbf{1}}-\mathbf{R} \mathbf{u}_{12}$, it appeared important to synthesize an intermediate compound, i.e. the generation zero $\left(\mathbf{G}_{0}\right.$ $\mathbf{R} \mathbf{u}_{6}$ ). This compound is synthesized as were $\mathbf{G}_{\mathbf{1}}-\mathbf{R} \mathbf{u}_{\mathbf{1 2}}, \mathbf{G}_{\mathbf{2}}-\mathbf{R} \mathbf{u}_{\mathbf{2 4}}$, and $\mathbf{G}_{\mathbf{3}}-\mathbf{R} \mathbf{u}_{48}$ [27], as shown in Scheme 2. Starting from $\mathbf{1}-\mathbf{G}_{\mathbf{0}}$, the first step is the reduction of the aldehydes with $\mathrm{BH}_{3} . \mathrm{SMe}_{2}$, to afford benzylalcohol terminal functions $\left(\mathbf{2}-\mathbf{G}_{\mathbf{0}}\right)$. The second step is the chlorination of the alcohols with $\mathrm{SOCl}_{2}$, to afford benzylchloride terminal functions (3-G) The third step is the alkylation of one nitrogen of PTA by the benzylchloride, affording $\mathbf{G}_{0}$. The $\mathrm{Ru}$ complex $\mathbf{G}_{\mathbf{0}}-\mathbf{R u}_{\mathbf{6}}$ is obtained in the last step, using the dimer $\left[\mathrm{RuCl}_{2}(p \text {-cymene) }]_{2}\right.$. The four compounds are in particular characterized by multinuclear NMR. The completion of the reactions on all terminal functions is assessed by ${ }^{1} \mathrm{H}$ NMR, which displays different signals on going from the aldehydes of $\mathbf{1}-\mathbf{G}_{\mathbf{0}}(\delta \mathrm{CHO}=9.9 \mathrm{ppm})$, to the benzylalcohols of $\mathbf{2}-\mathbf{G}_{\mathbf{0}}(\delta$ $\left.\mathrm{CH}_{2} \mathrm{OH}=4.47 \mathrm{ppm}\right)$, then to the benzylchlorides of $\mathbf{3}-\mathbf{G}_{\mathbf{0}}\left(\delta \mathrm{CH}_{2} \mathrm{Cl}=4.59 \mathrm{ppm}\right)$, and finally to the ammonium of PTA of $\mathbf{G}_{0}\left(\delta \mathrm{CH}_{2} \mathrm{~N}=4.22 \mathrm{ppm}\right)$. In ${ }^{31} \mathrm{P}$ NMR, two signals are observed for $\mathbf{G}_{\mathbf{0}}$ and $\mathbf{G}_{\mathbf{0}}-\mathbf{R u}_{\mathbf{6}}$, corresponding to the cyclotriphosphazene core, and the PTA. The latter signal shifted from -83.7 ppm for $\mathbf{G}_{\mathbf{0}}$ (free PTA) to -18.1 ppm for $\mathbf{G}_{\mathbf{0}}-\mathbf{R} \mathbf{u}_{\mathbf{6}}$ (complexed PTA), showing unambiguously the complexation of PTA with $\mathrm{Ru}$. Dendrimer $\mathbf{G}_{\mathbf{0}}-\mathbf{R u}_{\mathbf{6}}$ is fairly soluble in water and in phosphate buffer. 


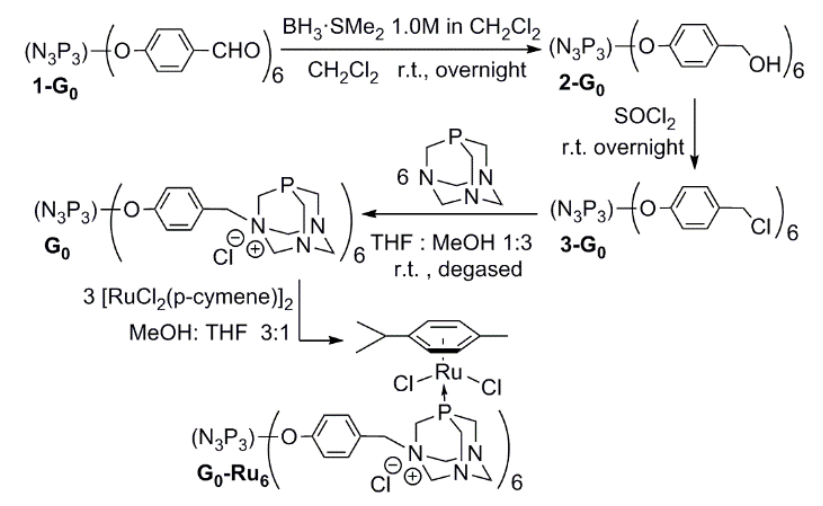

Scheme 2. Synthesis of the dendrimer of generation 0 , functionalized by PTA $\left(\mathbf{G}_{\mathbf{0}}\right)$, and of the corresponding ruthenium complex $\left(\mathbf{G}_{0}-\mathbf{R} \mathbf{u}_{6}\right)$.

It is well known that the anticancer drug cisplatin binds covalently to DNA, with concomitant bending and unwinding of the double helix [54]. Thus, as a first assay, we studied the interaction of the Ru complexes with supercoiled DNA, to detect if this interaction could lead to the relaxed form of DNA, and in comparison with cisplatin. Such assay is widely used for testing potential anti-cancer compounds; it enables testing compounds as a previous screening, to further focus on the most interesting ones for in vivo assays. Tests on cell cultures only provide another step (rarely conclusive) to assess the utility of a given compound as anticancer drug.

The complexes were first dissolved in phosphate buffer. Compounds $\mathbf{M}-\mathbf{R u}$ and $\mathbf{G}_{\mathbf{0}}-\mathbf{R u}_{\mathbf{6}}$ are soluble, dendrimers $\mathbf{G}_{\mathbf{1}}-\mathbf{R} \mathbf{u}_{12}$, and $\mathbf{G}_{\mathbf{2}}-\mathbf{R} \mathbf{u}_{\mathbf{2}}$ are poorly soluble. Experiments were performed at a fixed DNA amount and different concentrations of the Ru complexes were assayed. The Ri ratios, expressed as $\mathrm{Ru}$ atoms per base of DNA, are indicated in Figure 7. As it is shown, Ri values at which the complete conversion of supercoiled (SC) to relaxed DNA (OC) is achieved (coalescence point) differ for the different complexes. 

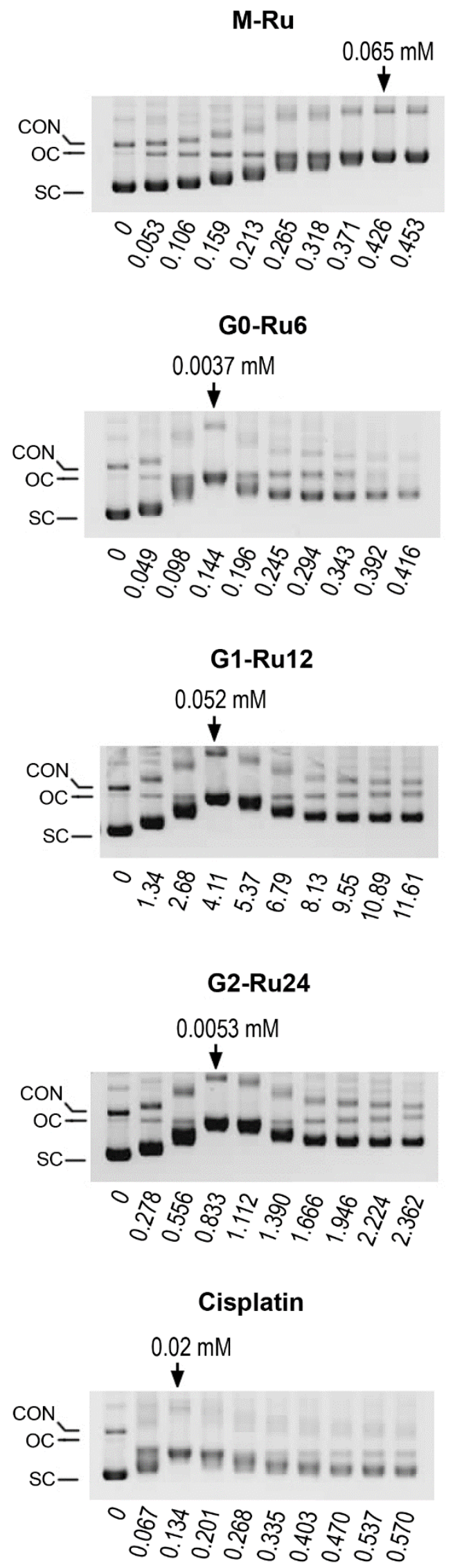
Figure 7. DNA mobility shift assay of Ru complexes (from up to down $\mathbf{M}-\mathbf{R u}, \mathbf{G}_{0}-\mathbf{R u}_{6}, \mathbf{G}_{\mathbf{1}}$ $\mathbf{R} \mathbf{u}_{12}$, and $\left.\mathbf{G}_{2}-\mathbf{R} \mathbf{u}_{24}\right)$ and of cisplatin. SC: supercoiled DNA. OC: open circular DNA. CON: plasmid concatemers. The Ri ( $\mathrm{Ru} / \mathrm{DNA}$ base molar ratio) values are shown below for each assay. Molecular complex concentrations to achieve the coalescent point for each complex are indicated by an arrow.

$\mathrm{Ri}$ values are similar for compound $\mathbf{G}_{\mathbf{0}}-\mathbf{R u}_{\mathbf{6}}$ and cisplatin, while they are increasingly higher for $\mathbf{M}-\mathbf{R u}, \mathbf{G}_{\mathbf{2}}-\mathbf{R} \mathbf{u}_{24}$ and $\mathbf{G}_{1}-\mathbf{R} \mathbf{u}_{12}$, respectively. The Ri values in Figure 7 are expressed in Moles of $\mathrm{Ru}$, as was done in the catalysis experiments, but it is interesting to calculate the Moles of compounds at which the coalescence occurred. This molar concentration is 0.065 $\mathrm{mM}$ for $\mathbf{M}-\mathbf{R u}, 0.0037 \mathrm{mM}$ for $\mathbf{G}_{\mathbf{0}}-\mathbf{R} \mathbf{u}_{\mathbf{6}}, 0.052 \mathrm{mM}$ for $\mathbf{G}_{\mathbf{1}}-\mathbf{R} \mathbf{u}_{\mathbf{1 2}}$, and $0.0053 \mathrm{mM}$ for $\mathbf{G}_{\mathbf{2}}-\mathbf{R} \mathbf{u}_{\mathbf{2}}$, to be compared to $0.02 \mathrm{mM}$ for cisplatin. Thus, two compounds are more active than cisplatin when expressed in molar concentrations $\left(\mathbf{G}_{0}-\mathbf{R} \mathbf{u}_{\mathbf{6}}\right.$ and $\left.\mathbf{G}_{2}-\mathbf{R} \mathbf{u}_{24}\right)$, but only one $\left(\mathbf{G}_{0}-\mathbf{R} \mathbf{u}_{6}\right)$ compares well with cisplatin when considering the concentration in metal (as for the Ri values).

As the poor efficiency (high Ri values) of the largest dendrimers, $\mathbf{G}_{\mathbf{1}}-\mathbf{R} \mathbf{u}_{\mathbf{1 2}}$, and $\mathbf{G}_{\mathbf{2}}-\mathbf{R} \mathbf{u}_{\mathbf{2 4}}$, might be related to their poor solubility, another experiment was carried out by dissolving first the complexes in DMSO, in which all of them are fairly soluble, and then adding this solution in the phosphate buffer. All compounds remained soluble in these conditions, but the results of the DNA mobility shift assay were not very different from those shown in Figure 7 . In particular, no real improvement was observed for compounds $\mathbf{G}_{\mathbf{1}}-\mathbf{R} \mathbf{u}_{\mathbf{1 2}}$, and $\mathbf{G}_{\mathbf{2}}-\mathbf{R} \mathbf{u}_{24}$.

\section{Conclusion}

The most well-known dendrimers can be often synthesized up to high generations (large size), as illustrated by the synthesis of PAMAM dendrimers up to generation 10 [55], of phosphorhydrazone dendrimers up to generation 12 [56], and even of triazine dendrimers up to generation 13 [57]. In most cases the best properties are obtained with generation 4 to 6 , but in some cases the first generation is the best, in particular for biological experiments [12]. In this paper, we have shown that in different conditions the ruthenium complex (preferably formed in situ than preformed) of the first generation dendrimer ended by PTA is the best for catalyzing the hydration of phenylacetylene, compared to the corresponding second and third generations of the dendrimers, and compared to the monomer. The same family of compounds has been tested for unwinding supercoiled DNA. In that case, the generation 0 is the best, displaying an efficiency similar to that of cisplatin. 
Thus in some cases, smaller is better, but not too small, as the multivalency, which is already obtained with generations 0 or 1 , offers better results than with a monomer. This is an interesting aspect of this work: the synthesis of dendrimers is generally a lengthy process but the multivalency effect can be observed even with low generations, easily synthesized, and less costly. Furthermore, we have shown that a same family of dendrimers can be useful in two very different topics, thus opening new perspectives for dendrimers.

\section{Acknowledgements.}

Thanks are due to the CNRS (France) and to the EU COST CM1302 SIPs for financial support. Thanks are given to the European Commission FEDER program for co-financing the project CTQ2015-67384-R (MINECO).

\section{References}

[1] A.-M. Caminade, C.-O. Turrin, R. Laurent, A. Ouali, B. Delavaux-Nicot, Editors, Dendrimers: Towards Catalytic, Material and Biomedical Uses, John Wiley \& Sons Ltd., Chichester, UK, 2011.

[2] D.A. Tomalia, H. Baker, J. Dewald, M. Hall, G. Kallos, S. Martin, J. Roeck, J. Ryder, P. Smith, Polymer J., 17 (1985) 117-132.

[3] E.M.M. de Brabander van den Berg, E.W. Meijer, Angew. Chem.-Int. Edit. Engl., 32 (1993) 1308-1311.

[4] A.M. Caminade, Chem. Soc. Rev., 45 (2016) 5174-5186.

[5] L.L. Zhou, N. Hadjichristidis, P.M. Toporowski, J. Roovers, Rubber Chem. Technol., 65 (1992) 303-314.

[6] N. Launay, A.M. Caminade, R. Lahana, J.P. Majoral, Angew. Chem.-Int. Edit. Engl., 33 (1994) 1589-1592.

[7] M. Slany, M. Bardaji, A.M. Caminade, B. Chaudret, J.P. Majoral, Inorg. Chem., 36 (1997) 1939-1945.

[8] A.M. Caminade, P. Servin, R. Laurent, J.P. Majoral, Chem. Soc. Rev., 37 (2008) 56-67.

[9] E. Badetti, A.M. Caminade, J.P. Majoral, M. Moreno-Manas, R.M. Sebastian, Langmuir, 24 (2008) 2090-2101.

[10] M. Keller, V. Colliere, O. Reiser, A.M. Caminade, J.P. Majoral, A. Ouali, Angew. Chem. Int. Ed., 52 (2013) 3626-3629.

[11] P. Neumann, H. Dib, A.M. Caminade, E. Hey-Hawkins, Angew. Chem. Int. Ed., 54 (2015) 311-314. 
[12] L. Griffe, M. Poupot, P. Marchand, A. Maraval, C.O. Turrin, O. Rolland, P. Metivier, G. Bacquet, J.J. Fournie, A.M. Caminade, R. Poupot, J.P. Majoral, Angew. Chem. Int. Ed., 46 (2007) 2523-2526.

[13] M. Hayder, M. Poupot, M. Baron, D. Nigon, C.O. Turrin, A.M. Caminade, J.P. Majoral, R.A. Eisenberg, J.J. Fournie, A. Cantagrel, R. Poupot, J.L. Davignon, Sci. Transl. Med., 3 (2011) 11.

[14] E. Blattes, A. Vercellone, H. Eutamene, C.O. Turrin, V. Theodorou, J.P. Majoral, A.M. Caminade, J. Prandi, J. Nigou, G. Puzo, Proc. Natl. Acad. Sci. U. S. A., 110 (2013) 87958800 .

[15] A.M. Caminade, S. Fruchon, C.O. Turrin, M. Poupot, A. Ouali, A. Maraval, M. Garzoni, M. Maly, V. Furer, V. Kovalenko, J.P. Majoral, G.M. Pavan, R. Poupot, Nature Communications, 6 (2015) 7722.

[16] A.M. Caminade, A. Ouali, R. Laurent, C.O. Turrin, J.P. Majoral, Coord. Chem. Rev., 308 (2016) 478-497.

[17] A. Ouali, R. Laurent, A.M. Caminade, J.P. Majoral, M. Taillefer, J. Am. Chem. Soc., 128 (2006) 15990-15991.

[18] N. El Brahmi, S. El Kazzouli, S.M. Mignani, E. Essassi, G. Aubert, R. Laurent, A.M. Caminade, M.M. Bousmina, T. Cresteil, J.P. Majoral, Mol. Pharm., 10 (2013) 1459-1464.

[19] M.F. Ottaviani, N. El Brahmi, M. Cangiotti, C. Coppola, F. Buccella, T. Cresteil, S. Mignani, A.M. Caminade, J.P. Costes, J.P. Majoral, RSC Advances, 4 (2014) 3657336583.

[20] A.M. Caminade, J.P. Majoral, Prog. Polym. Sci., 30 (2005) 491-505.

[21] A.M. Caminade, A. Hameau, J.P. Majoral, Chem.-Eur. J., 15 (2009) 9270-9285.

[22] M.Y. Darensbourg, D. Daigle, Inorg. Chem., 14 (1975) 1217-1218.

[23] R. Mejia-Rodriguez, D. Chong, J.H. Reibenspies, M.P. Soraga, M. Y. Darensbourg, J. Am. Chem. Soc., 126 (2004) 12004-12014.

[24] M.S. Ruiz, A. Romerosa, B. Sierra-Martin, A. Fernandez-Barbero, Angew. Chem. Int. Ed., 47 (2008) 8665-8669.

[25] M. Serrano-Ruiz, S. Imberti, L. Bernasconi, N. Jadagayeva, F. Scalambra, A. Romerosa, Chem. Commun., 50 (2014) 11587-11590.

[26] M. Zablocka, A. Hameau, A.M. Caminade, J.P. Majoral, Adv. Synth. Catal., 352 (2010) 2341-2358.

[27] P. Servin, R. Laurent, L. Gonsalvi, M. Tristany, M. Peruzzini, J.P. Majoral, A.M. Caminade, Dalton Trans., (2009) 4432-4434. 
[28] N. Launay, A.M. Caminade, J.P. Majoral, J. Organomet. Chem., 529 (1997) 51-58.

[29] L. Hintermann, A. Labonne, Synthesis (2007) 1121-1150.

[30] F. Alonso, I.P. Beletskaya, M. Yus, Chem. Rev., 104 (2004) 3079-3159.

[31] M. Tokunaga, Y. Wakatsuki, Angew. Chem. Int. Ed., 37 (1998) 2867-2869.

[32] S. Sanz, L.A. Jones, F. Mohr, M. Laguna, Organometallics, 26 (2007) 952-957.

[33] M.J. Payne, D.J. Cole-Hamilton, J. Chem. Soc.-Dalton Trans., (1997) 3167-3175.

[34] Y. Abedi, A. Biffis, R. Gava, C. Tubaro, C. Chelucci, S. Stoccoro, Applied Organomet. Chem., 28 (2014) 512-516.

[35] A. Phanopoulos, A.J.P. White, N.J. Long, P.W. Miller, ACS Catal., 5 (2015) 2500-2512.

[36] C. Walter, R. Fröhlich, M. Oestreich, Tetrahedron, 65 (2009) 5513-5520.

[37] Y. Sun, W.R. Thiel, Inorg. Chim. Acta, 359 (2006) 4807-4810.

[38] S.L. Rumble, M.J. Page, L.D. Field, B.A. Messerle, Eur. J. Inorg. Chem., (2012) 22262231.

[39] Y. Suzuki, B. Sun, T. Yoshino, M. Kanai, S. Matsunaga, Tetrahedron, 71 (2015) 45524556.

[40] A.J.J. Lennox, S. Fischer, M. Jurrat, S.P. Luo, N. Rockstroh, H. Junge, R. Ludwig, M. Beller, Chem. Eur. J., 22 (2016) 1233-1238.

[41] A. Demonceau, A.W. Stumpf, E. Saive, A.F. Noels, Macromolecules, 30 (1997) 31273136.

[42] L. Delaude, A. Demonceau, Dalton Trans., 41 (2012) 9257-9268.

[43] V. Cadierno, P. Crochet, S.E. Garcia-Garrido, J. Gimeno, Dalton Trans., (2004) 36353641 .

[44] F. Boeck, T. Kribber, L. Xiao, L. Hintermann, J. Amer. Chem. Soc. 133 (2011) 81388141.

[45] B. Breit, U. Gellrich, T. Li, J.M. Lynam, L.M. Milner, N.E. Pridmore, J.M. Slattery, A.C. Whitwood, Dalton Trans. 43 (2014) 11277-11285.

[46] A.M. Caminade, A. Ouali, R. Laurent, C.O. Turrin, J.P. Majoral, Chem. Soc. Rev. 44 (2015) 3890-3899.

[47] A. Perrier, M. Keller, A.M. Caminade, J.P. Majoral, A. Ouali, Green Chem., 15 (2013) 2075-2080

[48] E.S. Antonarakis, A. Emadi, Cancer Chemother. Pharmacol., 66 (2010) 1-9.

[49] A. Bergamo, C. Gaiddon, J.H.M. Schellens, J.H. Beijnen, G. Sava, J. Inorg. Biochem. 106 (2012) 90-99. 
[50] L. Hajji, C. Saraiba-Bello, A. Romerosa, G. Segovia-Torrente, M. Serrano-Ruiz, P. Bergamini, A. Cannella, Inorg. Chem., 50 (2011) 873-882.

[51] C. Rios-Luci, L.G. Leon, A. Mena-Cruz, E. Perez-Roth, P. Lorenzo-Luis, A. Romerosa, J.M. Padron, Bioorg. Med. Chem. Lett., 21 (2011) 4568-4571.

[52] M. Serrano-Ruiz, L.M. Aguilera-Saez, P. Lorenzo-Luis, J.M. Padron, A. Romerosa, Dalton Trans., 42 (2013) 11212-11219.

[53] Z. Mendoza, P. Lorenzo-Luis, M. Serrano-Ruiz, E. Martín-Batista, J. M. Padrón, F. Scalambra, A. Romerosa, Inorg. Chem., 55 (2016) 7820-7822.

[54] S.F. Bellon, J.H. Coleman, S.J. Lippard, Biochemistry, 30 (1991) 8026-8035.

[55] D.A. Tomalia, A.M. Naylor, W.A. Goddard, Angew. Chem.-Int. Edit. Engl., 29 (1990) 138-175.

[56] M.L. Lartigue, B. Donnadieu, C. Galliot, A.M. Caminade, J.P. Majoral, J.P. Fayet, Macromolecules, 30 (1997) 7335-7337.

[57] J. Lim, M. Kostiainen, J. Maly, V.C.P. da Costa, O. Annunziata, G.M. Pavan, E.E. Simanek, J. Am. Chem. Soc., 135 (2013) 4660-4663. 